\title{
Information and education environment as a condition of senior students' cognitive activity growing using ICT
}

\author{
Grytsiuk 0.;, Shapoval 0., Opryshko A.
}

Kremenchuk Mykhailo Ostrohradskyi National University, Kremenchuk, Ukraine

Kremenchuk Pravobereghnyi Lyceum № 6 Kremenchuk Town Council Poltava region, Kremenchuk, Ukraine

Received: $12.03 .2019 \quad$ Accepted: 10.04 .2019

\begin{abstract}
The purpose of the paper is to study the effectiveness of the use of informational and educational environment during the study of students of the training course «Informatics» to enhance their cognitive activity. The use of educational technologies with the use of ICT tools allows you to modify the entire teaching process, implement a model of student-centered learning, intensify classes by improving cognitive activity, and most importantly, improve senior students' self-training. The main tasks of modern pedagogical technologies using ICT tools are the development of interactive environments for managing the cognitive activity process, access to modern information and educational resources (multimedia textbooks, various databases, educational sites and other sources). The informational and educational environment is based on the integration of information on traditional and electronic media, computer-telecommunication interaction technologies, virtual libraries, distributed databases, educational and methodical complexes and an extended didactic device. In the concept of information-educational environment, the pedagogical system and its support are combined. The scientific novelty of the paper includes analysis of the works of scientists on increasing the cognitive activity of students through means of ICT and improving the forms of organizing classes in computer science using ICT tools. The article presents informational and educational environment for the study of computer science in secondary schools, namely Internet portal «Virtual office of computer science and ICT». The purpose of creating an Internet portal is to coordinate the efforts of all participants in the educational process (students, teachers, parents), the organization of educational and non-academic work, as well as the activation of cognitive activity of students during the study of computer science. The practical value of the study is to refine the concepts of "cognitive activity», "educational activity», "cognitive interest», the development and improvement of technology for raising senior students' cognitive activity by solving mathematical problems by means of computer mathematics at computer science lessons. The use of computer mathematics as an educational tool makes it possible to rethink traditional approaches to the study a lot of issues of computer science and mathematics, to increase the experimental activity of students, to bring the learning process closer to the real cognition process.
\end{abstract}

Key words: information and communication technologies, informational and educational environment, automated educational system, cognitive activity.

\section{Інформаційно-освітнє середовище як умова активізації пізнавальної діяльності учнів засобами IKT}

\author{
Грицюк О. С., Шаповал О. А., Опришко А. В. \\ Кременчуцький національний університет імені Михайла Остроградського, Кременчук, Україна \\ Кременчуцький ліцей № 6 «Правобережний» Кременчуцької міської ради Полтавської області, Кременчук, Україна
}

\begin{abstract}
Анотація. У статті проаналізовано методологічні й організаційні аспекти створення інформаційно-освітнього середовища 3 метою активізації пізнавальної діяльності учнів засобами ІКТ. Застосування педагогічних технологій з використанням засобів ІКТ дозволяє видозмінювати весь процес викладання, реалізовувати модель особистісно-орієнтованого навчання, інтенсифікувати заняття шляхом підвищення пізнавальної активності, а головне - удосконалювати самопідготовку учнів. Основними завданнями сучасних педагогічних
\end{abstract}

\footnotetext{
Corresponding Author: Grytsiuk Olena Serhiivna.+38(05366)31147. E-mail: myboxua13@gmail.com. Kremenchuk Mykhailo Ostrohradskyi National University,

Pershotravneva st, 20, Kremenchuk, Ukraine, 39600

Biдnовідальний автор: Грицюк Олена Сергіївна. +38(05366)3-11-47. E-mail: myboxua13@gmail.com. Кременчуцький національний університет імені Михайла Остроградського, вул. Першотравнева, 20, м. Кременчук, Україна, 39600.
} 
технологій з використанням засобів ІКТ $€$ розробка інтерактивних середовищ управління процесом пізнавальної діяльності, доступу до сучасних інформаційно-освітніх ресурсів (мультимедійних підручників, різноманітних баз даних, навчальних сайтів та інших джерел). У статті репрезентовано інформаційно-освітнє середовище для вивчення інформатики у загальноосвітніх навчальних закладах, а саме інтернет-портал «Віртуальний кабінет інформатики й ІКТ». Метою створення інтернет-порталу $є$ координація зусиль усіх учасників освітнього процесу (учнів, учителів, батьків), організація навчальної та поза навчальної роботи, а також активізація пізнавальної діяльності учнів під час вивчення інформатики.

Ключові слова: інфрормаційно-комунікаційні технології, інформаційно-освітнє середовище, автоматизована освітня система, пізнавальна активність.

\title{
Информационно-образовательная среда как условие активизации познавательной деятельности учащихся средствами ИКТ
}

\author{
Грицюк Е. С., Шаповал Е. А., Опрышко А. В.
}

Кременчугский национальный университет имени Михаила Остроградского, Кременчуг, Украина

Кременчугский лицей №6 «Правобережный» Кременчугского городского совета Полтавской области, Кременчуг, Украина

\begin{abstract}
Аннотация. В статье проанализированы методологические и организационные аспекты создания информационно-образовательной среды с целью активизации познавательной деятельности учащихся средствами ИКТ. Применение педагогических технологий с использованием средств ИКТ позволяет видоизменять весь процесс преподавания, реализовывать модель личностно-ориентированного обучения, интенсифицировать занятия путем повышения познавательной активности, а главное - совершенствовать самоподготовку учащихся. Основными задачами современных педагогических технологий с использованием средств ИКТ является разработка интерактивных сред управления процессом познавательной деятельности, доступ к современным информационно-образовательным ресурсам (мультимедийным учебникам, различным базам данных, учебным сайтам и другим источникам). В статье представлена информационнообразовательная среда для изучения информатики в общеобразовательных учебных заведениях, а именно интернет-портал «Виртуальный кабинет информатики и ИКТ». Целью создания интернет-портала является координация усилий всех участников образовательного процесса (учеников, учителей, родителей), организация учебной и внеучебной работы, а также активизация познавательной деятельности учащихся при изучении информатики.
\end{abstract}

Ключевые слова: информационно-коммуникационные технологии, информационно-образовательная среда, автоматизированная образовательная система, познавательная активность.

\section{Bcmyn}

Однією з проблем педагогіки є розвиток пізнавальної активності, способів і методів активізації навчальної діяльності. До неї звертаються психологи, педагоги, навіть філософи. У численних статтях, різноманітних дослідженнях, наукових розвідках вона обросла тлумаченнями, уточненнями, точками зору, проте у Державному освітньому стандарті закладів середньої освіти вона зазначена як одна з центральних педагогічних проблем.

Пізнавальна активність - це основа підготовки молодого покоління до продуктивної профресійної діяльності, це й умова духовного розвитку особистості, й умова розвитку самостійності особистості, підвищення рівня їі творчого потенціалу; пізнавальна активність $є$ важливою умовою вдосконалення і одночасно показником ефективності навчально-виховного процесу [1].

Пізнавальна активність формується на основі як об'єктивних, так і суб'єктивних факторів. До перших належать особистісні характеристики учня - старанність, мотивація навчання, допитливість, цікавість до нового тощо. Об'єктивні фактори забезпечуються навчальним середовищем і залежать переважно від учителя, від його вміння і бажання впроваджувати новітні педагогічні методи і технології навчання.

Активізація пізнавальної діяльності передбачає певну стимуляцію, посилення процесу пізнання. Самопізнання можна представити як послідовний ланцюг, що складається з сприйняття, запам'ятовування, збереження, осмислення, відтворення та інтерпретації отриманих знань.

Інформатизація всіх галузей, активне використання інформаційно-комунікаційних технологій (IКТ) у повсякденному житті, вимоги Державного освітнього стандарту, згідно 3 яким впровадження інноваційних технологій покликане, насамперед, поліпшити якість навчання, підвищити мотивацію учнів до отримання нових знань, прискорити процес засвоєння знань, призвели до необхідності вивчення 
різноманітного програмного забезпечення. 3 метою засвоєння в найкоротші терміни досить великої кількості навчального матеріалу необхідно розвивати пізнавальну активність.

Актуальні проблеми педагогічних досліджень у галузі використання IKT в освіті висвітлюються у розвідках В. Бикова та М. Лещенко [2], Дж. Малача, К. Костолянової, М. Чмури, І. Нагійової, Т. Прекстової [3], І. Симонової, Т. Устюгової та О. Яковлевої [4]. Взаємодії учасників освітнього процесу в комп'ютерно-орієнтованому навчальному середовищі присвячені праці Т. Поясок і О. Беспарточной [5], Н. Бахмат і А. Карташовой [6], Н. Морзе і А. Буйницької [7; 8], В. Хиврич [10]. Питання організації інформаційно-освітнього середовища з метою підвищення пізнавальної активності учнів засобами ІКТ розглядають вчені-дидакти (Т. Мукій [11], Л. Колток [12]. В. Лапінський [13], Ю. Триус [14]), а також вчителіпрактики (М. Бистрянцев [15], С. Гаврилюк [16], Т. Гашпоренко [17], М. Головата [18]).

Meта роботи: дослідити ефективність використання інформаційно-освітнього середовища під час вивчення учнями загальноосвітніх шкіл навчального курсу «Інформатика» для підвищення їхньої пізнавальної активності.

\section{II Матеріал і методи дослідження}

Для розв'язання поставлених завдань використано методи: теоретичний - для вивчення й аналізу науково-педагогічної літератури, навчальних програм, посібників, узагальнення інформації для визначення теоретико-методологічних основ дослідження; метод опису інтерактивних форм навчання.

Сучасний етап розвитку сфрери освіти характеризується масовим впровадженням інформаційних і телекомунікаційних технологій у діяльність всіх учасників освітнього процесу. Інфоорматизація є одним 3 основних фракторів, що змушують освіта вдосконалюватися. Розвиваються зміст і методи навчання, змінюється роль педагога, який поступово перетворюється з транслятора знань в організатора діяльності учнів по придбанню нових знань, умінь і навичок. Істотним засобом інформатизації виступають освітні інформаційні ресурси, опубліковані в мережі Інтернет. Не випадково їх своєчасне та коректне використання усіма фахівцями, які працюють в системі загальної освіти, служить запорукою ефективної підготовки учнів.

Невід'ємною частиною будь-якого уроку є розв'язання різних задач, виконання завдань. На уроці інформатики учні виконують завдання як практичного, так і теоретичного характеру. Проблема, з якою стикається будь-який педагог, полягає в тому, що ані зміст стандартних шкільних завдань, ані процес їх рішення зазвичай не викликають у учня пізнавального інтересу і бажання працювати. Тому для підвищення пізнавального інтересу доцільно застосовувати творчі завдання з використанням IКТ. 3 цього приводу Л. Колток зауважує, що сучасні мультимедійні технології надають можливості інтеграції таких важливих передумов для організації навчально-виховного процесу, як мотивація, наочність, індивідуалізація навчальної діяльності, а також організації ефективного моніторингу за навчальною діяльністю з боку вчителя [12].

Г. Панченко і А. Шевченко зазначають, що актуалізація продуктивної, творчої пошукової діяльності відбувається завдяки педагогічній взаємодії в інформаційно-освітньому середовищі [19].

Освітнє середовище - це суттєвий елемент соціуму, цілеспрямовано організована, керована, багатофункціональна, відкрита педагогічна система, в межах якої учень загальноосвітньої школи усвідомлює себе як соціально розвинену цілісність [20].

Водночас, інфрормаційно-освітнє середовище передбачає поєднання інформаційно-технічного та навчально-методичного забезпечення. У сучасних умовах інформаційно-освітнє середовище $є$ однією 3 основних засад ефективного функціонування освітнього простору, адже завдяки ньому здійснюється доступ до інформації, налагоджуються комунікативні канали між учасниками освітнього процесу педагогічним колективом, учнями і батьками.

\section{III Результати}

Сучасне шкільне інформаційно-освітнє середовище поєднує педагогічні технології з інфрормаційно-комп'ютерними, навчально-методичну та дидактичну інформацію з енциклопедичною та довідковою інформації. Таким чином, воно стає підґрунтям інтеграції різноманітних компонентів навчального і освітнього процесів. 
Ресурси інформаційно-освітнього середовища містять технологічну складову (мультимедійне обладнання і програмне забезпечення), інформаційну складову (масив навчальної, довідкової та дидактичної інформації), організаційну складову (система впорядкування діяльності), кадрову складову (педагогічний колектив).

Варто зауважити, що інформаційно-освітнє середовище закладу останнім часом стає чинником активізації діяльності не лише учнів, а й учителів, адже завдяки ньому педагогічні працівники долучаються до можливості обмінюватися новими знаннями та актуальною інформацією (навчального й дидактичного характеру), оволодівати інноваційними педагогічними технологіями і методиками. Віртуальний простір створює умови для самовдосконалення і підвищення ІКТ-кваліфікації вчителів, і, унаслідок, - модернізації шкільної освіти, наближення її до світових зразків. Н. Морзе та О. Буйницька справедливо зазначають, що підвищення рівня інформаційно-комунікаційної компетентності науковопедагогічних працівників $є$ ключовою вимогою якості освітнього процесу [9].

Виходячи з цього, одним з завдань сучасної педагогічної інноватики є організація та управління процесом активізації пізнавальної діяльності учнів та учителів шляхом створення ефективного інформаційно-освітнього середовища, яке забезпечує інтерактивний доступ до великого масиву навчальної та наукової інформації.

Важливими напрямками роботи загальноосвітньої школи в умовах інформаційно-освітнього середовища є:

- організація неперервної самоосвіти вчителів (це стосується підвищення кваліфікації у галузі дидактики й у галузі IKT);

- участь учнів і вчителів у освітніх проектах (у тому числі й міжнародних), які стосуються впровадження ІКТ у освітню діяльність);

- впровадження міждисциплінарних зв'язків, зокрема, проведення інтегрованих уроків з використанням IКТ і мультимедійного обладнання;

- проведення онлайн-конференцій, форумів, тренінгів і мастер-класів з іншими освітніми закладами та іншими установами;

- створення коворкінгів для спілкування та творчої взаємодії учнів та учителів;

- створення спільних проектів (суспільного та наукового характеру);

- організація різноманітних форм учнівського самоврядування.

Сучасне інформаційно-освітнє середовище загальноосвітньої школи складається з локальної шкільної мережі, до якої підключені усі комп'ютери школи, і яка має вихід в Інтернет, мультимедійних комплексів, програмного забезпечення.

Системне, ефективне формування інформаційної компетенції, передбаченої навчальною програмою «нфформатика» [21], для основної маси вчителів і учнів сьогодні можливо лише за умови використання інформаційно-комунікативних технологій. А отже, успішність визначаються середню освіту перетворень багато в чому залежить від їх застосування. Іншими словами, інформатизація - це найважливіший напрям модернізації системи середньої освіти в Україні.

Інформаційно-комунікаційні технології - сукупність сучасної комп'ютерної техніки, засобів телекомунікаційного зв'язку, інструментальних програмних засобів, що забезпечують інтерактивний програмно-методичний супровід інноваційних педагогічних технологій.

Застосування педагогічних технологій з використанням засобів ІКТ дозволяє видозмінювати весь процес викладання, реалізовувати модель особистісно-орієнтованого навчання, інтенсифікувати заняття шляхом підвищення пізнавальної активності, а головне - удосконалювати самопідготовку учнів.

Впровадження інформаційно-освітнього середовища докорінно змінюе форми спілкування вчителя і учнів, додаючи до навчання елементи ділового співробітництва та науково-пошукової діяльності. Це сприяє підвищенню мотивації навчання, створенню нових фрорм і моделей навчальної діяльності, діагностики знань та підсумкового контролю (доповіді, презентації, звіти, публічні захисти індивідуальних і групових проектів), підвищує індивідуальність і інтенсивність навчання, а отже, і пізнавальну активність учнів.

IКТ надають великі можливості в розвитку творчості як вчителя, так і учнів. С. Гаврилюк зауважує, що за урок учителю потрібно встигнути зробити багато чого: провести опитування, перевірити домашнє завдання, розібрати новий матеріал, закріпити його, побачити зростання кожного учня, створити ситуацію успіху. Урок зазвичай проходить в напруженому ритмі. Водночас, С. Гаврилюк вважає, що завдання вчителя - активізувати пізнавальну діяльність учня в процесі навчання. Сучасні педагогічні 
технології такі, як навчання в співробітництві, проектна методика, використання нових інформаційних технологій, Інтернет-ресурсів допомагають реалізувати особистісно-орієнтований підхід у навчанні, забезпечують індивідуалізацію і диференціацію навчання з урахуванням здібностей дітей, їхнього рівня навченості, схильностей і т.д. Навчити дитину працювати з інформацією, навчити навчатися - важливе завдання сучасної школи. Підвищення якості освіти за нашого часу неможливе без застосування нових інформаційно-комунікаційних технологій.

Звідси випливають виокремленні С. Гаврилюк завдання використання IKT:

- підвищення мотивації навчання;

- підвищення ефрективності процесу навчання;

- сприяння активізації пізнавальної сфери учнів;

- удосконалення методики проведення уроків;

- своєчасне відстеження результатів навчання і виховання;

- планування і систематизація роботи;

- використання в якості засобу самоосвіти;

- якісна і швидка підготовка уроку (заходу) [16].

До навчальних компонентів освітніх ІКТ належать:

- освітні портали;

- автоматизовані освітні системи;

- технічне забезпечення навчального процесу.

Важливою частиною інформаційно-освітнього середовища загальноосвітньої школи, яка призначена для організації навчальної діяльності, поглиблення знань, самостійного вивчення і підвищення пізнавальної активності учнів, як у процесі навчання, так і у позанавчальний та позаурочний час $€$ інтернет-портали з певних навчальних дисциплін. Інтернет-портали $€$ каталогами ресурсів. Прикладом подібного інтернет-порталу $є$ розроблений авторами «Віртуальний кабінет інформатики й IKT», створений для спільного використання учнями й учителями загальноосвітніх шкіл [22].

Метою створення інтернет-порталу $є$ координація зусиль усіх учасників освітнього процесу (учнів, учителів, батьків), організація навчальної та поза навчальної роботи, а також активізація пізнавальної діяльності учнів під час вивчення інформатики.

Серед освітніх IKT, які використовуються для створення шкільного інформаційно-освітнього середовища, як правило, домінують два типи:

- ресурси, що містять великі масиви текстової інформації (довідково-енциклопедичні, навчальнометодичні тощо);

- засоби моніторингу знань, тобто контролю та оцінки навчання.

На інтернет-порталі «Віртуальний кабінет інформатики й IKT» цей перелік було розширено за рахунок додавання комплексу матеріалів, спрямованих на активізацію пізнавальної діяльності учнів. На порталі розміщено:

- комплекс навчальних матеріалів для вивчення інфрорматики (електронні підручники, електронний словник-довідник «Енциклопедія комп'ютерних знань», комплекс уроків-презентацій з кожної теми, що вивчається);

- комплекс онлайн-тестів, виконання яких дозволяє здійснювати перевірки отриманих знань і вмінь. Онлайн-тестування може використовуватися одночасно й у процесі навчальних занять, і у вільний час, що дозволяє організувати оперативний контроль знань вчителями і батьками, а також самоперевірку знань учнями у поза навчальний час;

- електронний журнал моніторингу знань учнів. Вільний доступ до електронного журналу значно полегшує для учнів і батьків можливість отримати інформацію щодо поточних оцінок, а також знижує можливості необ'єктивного оцінювання з боку вчителя;

- комплекс творчих завдань для виконання у позаурочний час, який складається з двох частин. Перша містить ігрові завдання (ребуси, кросворди, задачі-парадокси, цікаві задачі тощо) і спрямована на оволодіння знаннями з інформатики в ігровій формі. Цей тип завдань подається переважно у візуальній формі (малюнки, відео), для того, щоб зацікавити учнів, привернути їхню увагу. Друга частина містить завдання-проекти, розраховані на тривалий час виконання. Завдання-проекти $€$ першою сходинкою до наукової діяльності. 
Для зручності користування цим ресурсом у процесі навчання назви окремих кнопок-меню відповідають розділам навчального курсу «Інформатика» (наприклад, меню порталу «Інформація та інформаційні процеси» відповідає розділу навчальної програми «Інформаційні процеси та системи»).

На уроках інформатики в школі для учнів початкової школи ознайомлення із засобами IКТ (програмною продукцією) доцільно починати з вивчення засобів ІКТ, що створюють інформаційноосвітнє середовище. До цих засобів ІКТ належать програмні інструкції, поради, рекомендації із широкого кола питань. 3 ними вчитель може проводити класні і позакласні заняття, звільняючи себе від багаторазового повторення, від суб'єктивності в оцінці навчальних успіхів учнів, допомагаючи їм освоювати технологію самонавчання.

\section{IV Обговорення}

Аналогічні інформаційно-освітні середовища створюються вчителями-практиками, які діляться досвідом роботи. Так, аналізуючи можливості використання засобів IКТ на уроках інформатики у школі, Т. Гашпоренко підкреслює той факт, що проведення уроку з використанням інформаційних технологій дозволяє перекласти частину своєї роботи на комп'ютер, що робить процес навчання більш цікавим й інтенсивним, забезпечує наочність, залучення великої кількості дидактичного матеріалу. ІКТ можна використовувати на будь-якому етапі уроку: у процесі актуалізації знань, вивчення нового матеріалу, закріплення, повторення вивченого, контролю, оцінювання. На думку Т. Гашпоренко, ІКТ приводить до підвищення зацікавленості дитини до навчання, що в свою чергу привчає учнів жити в інформаційному середовищі, сприяє залученню учнів до інформаційної культури, дозволяє активізувати пізнавальну діяльність [17].

Інформаційно-освітнє середовище загальноосвітньої школи передбачає використання автоматизованих освітніх систем (AOC) [22]. АОС $€$ сукупністю навчально-методичних матеріалів і спеціалізованих програм, що здійснюють організацію і управління навчальним процесом. Завдяки АОС навчальний матеріал з певних предметів подається у стислому, чітко побудованому вигляді (зазвичай у вигляді презентацій). До нього обов'язково додаються запитання для моніторингу знань чи тестові завдання, які забезпечують контроль і оцінку ефективності навчального процесу. Отже, АОС забезпечують налагодження зв'язків між учасниками навчального процесу, дозволяють адаптувати і коригувати навчальний матеріал, орієнтуючись на рівень знань і запити учнів.

Призначення довідково-інформаційних матеріалів полягає в тому, щоб забезпечити на уроці наочність і доказовість, використовувати ці програми для наведення різного роду довідок і для самоперевірки, для надання зразка виконання якого-небудь завдання на конкретному предметному матеріалі.

Довідково-інформаційні матеріали покликані полегшити багатьом учням освоєння шкільної програми, вони носять підтримуючий і супроводжуючий, нерідко й мотивуючий характер.

\section{V Висновки}

Розробка інформаційно-освітнього середовища для навчання інформатиці у загальноосвітній школі створює передумови для розкриття інтелектуального і творчого потенціалу учнів, підвищення мотивації до навчання і самонавчання.

Застосування сучасних педагогічних технологій, які передбачають широке впровадження у навчальний процес засобів IKT, сприяє реалізації моделі особистісно-орієнтованого навчання, інтенсифікації навчання завдяки підвищенню пізнавальної активності.

Використання інформаційно-освітнього середовища як інструменту навчальної діяльності надає можливість переосмислення традиційних підходів до вивчення інформатики, посилення експериментальної діяльності учнів, активізації їхньої пізнавальної діяльності, наближення процесу навчання до реального процесу пізнання. 


\section{Бібліографічні посилання}

[1] Лозова В. І. Цілісний підхід до формування пізнавальної активності школярів. 2-е вид., доп. Харків: ОВС, 2000. 164 с.

[2] Биков В. Ю., Лещенко М. П. Цифрова гуманістична педагогіка: актуальні проблеми педагогічних досліджень у галузі використання IКT в освіті. Інформаційні технології $i$ засоби навчання. 2016. T. 53, № 3. C. 1-17. DOI: https://doi.org/10.33407/ittl.v53i3.1417

[3] Objectives and Content of E-module "Tools for Adaptive Learning. Learning Styles" within the MOOC Course "ICT Tools for E-learning" / J. Malach et al. International Journal of Research in E-learning. 2016. Vol. 2, No. 1. P. $28-40$.

[4] Simonova I., Ustiugova T., Yakovleva O. The Impact of Online Services on Developing Students' Media Competence. International Journal of Research in E-learning. 2017. Vol. 3, No. 2. P. 35-48.

[5] Поясок Т.Б., Беспарточна О.І. Організація педагогічної взаємодії учасників освітнього процесу в комп'ютерно орієнтованому навчальному середовищі закладу вищої освіти. Інформаційні технології і засоби навчання. 2018. Т. 67, № 5. C. 199-212. DOI: https://doi.org/10.33407/ittt.v67i5.2110

[6] Bahmat N. V., Kartashova L. A. Organization of teacher's professional activity in conditions of innovative educational environment. Informational Technologies in Education. 2016. № 27. P. 31-40.

[7] Morze N., Buinytska O. E-learning Managers Training to Design High-tech Electronic Learning Environment. International Journal of Research in E-learning. 2016. Vol. 2, No. 2. P. 11-27.

[8] Morze N., Buinytska O. Open E-environment - The Key Instrument of the Education Quality. International Journal of Research in E-learning. 2015. Vol. 1, No. 1. P. 27-46.

[9] Морзе Н. В., Буйницька О. П. Підвищення рівня інформаційно-комунікаційної компетентності науково-педагогічних працівників - ключова вимога якості освітнього процесу. Інформаційні технології і засоби навчання. 2017. Т. 59, № 3, C. 189-200, DOI: https://doi.org/10.33407/itlt.v59i3.1667

[10] Khivrych V. The Experience of the Creation of Educational IT Space of the Region. International Journal of Research in Elearning. 2015. Vol. 1, No. 2. P. 70-85.

[11] Mukii T. V. The Development of Key Student Competencies While Studying Computer Science in Secondary School. International Journal of Research in E-learning. 2016. Vol.1, Iss. 2, P. 103-118.

[12] Колток Л. Використання ІКТ на уроках як одна із складових модернізації початкової школи. Молодь і ринок. 2015. № 9 (128). С. 112-116.

[13] Лапінський В. В. Комп'ютерно орієнтоване навчальне середовище та вимоги до його реалізації Наукові записки. Вип. 77. Серія: Педагогічні науки. Кіровоград: РВВ КДПУ ім. В. Винниченка, 2008. Ч. 1. С. 79-85.

[14] Триус Ю. В. Комп'ютерно-орієнтовані методичні системи навчання: монографрія. Черкаси: Брама-Україна, 2005. 400 с.

[15] Бистрянцев М. Створення інформаційно-освітнього простору загальноосвітньої школи. Рідна школа. 2016. № 10. С. 19-24.

[16] Гаврилюк C. Використання IKT на уроках інформатики. URL: https://lana01091966.io.ua/ s2289203/vikoristannya_ikt_na_urokah_informatiki (дата звернення: 04.03.2019).

[17] Гашпоренко Т.В.Використання інформаційно-комунікаційних технологій на уроках інформатики в початковій школі. Матеріали інтернет-конференції педагогічних працівників Центру методичної та соціально-психологічної служби м. Кропивницького (січень 2016). URL: http://cmsps.edukit.kr.ua/metodichna_robota//sichneva_internetkonferenciya_2016/pn/2/ (дата звернення: 12.03.2019).

[18] Головата М. Л. Використання інформаційно-комп'ютерних технологій на уроках інформатики та в позаурочний час. URL: http:/golovata.dimca.cv.ua/wp-content/uploads/2014/01/Використання-інфрормаційно-компютерних-технологій-науроках-інформатики-та-в-позаурочний-час.рdf. (дата звернення: 12.03.2019).

[19] Панченко Г. Д. Інформаційно-освітнє середовище в профресійній підготовці вчителя. Педагогічна освіта: теорія $i$ практика. 2012. Вип. 11. С. 69-81.

[20] Литвинова С. Розвиток навчального середовища загальноосвітнього навчального закладу як наукова проблема. Науковий вісник Мелітопольського державного педагогічного університету. Серія: Педагогіка. 2014. № 1 (12). С. 39-47.

[21] Інформатика для учнів 5-9 класів, які вивчали інформатику у 2-4 класах: навчальна програма / розроб.: M. I. Жалдак (голова групи) та ін. Київ: МОН України, 2017. 24 с. URL: https://mon.gov.ua/storage/app/media/zagalna serednya/programy-5-9-klas/onovlennya-12-2017/8-informatika.docx (дата звернення: 10.03.2019).

[22] Грицюк О.С. Комп'ютерно-орієнтоване навчальне середовище вчителя інформатики. Сучасний рух науки: тези доповідей IV Міжнародної науково-практичної інтернет-конференції (Дніпро, 6-7 грудня 2018 р.). Дніпро: WayScience, 2018. C. 318-323. URL: http://www.wayscience.com/wp-content/uploads/2018/12/Zbirnik-tez-dopovidey-IV-mizhnarodnoyinaukovo-praktichnoyi-internet-konferentsiyi.pdf (дата звернення: 11.03.2019).

\section{References}

[1] Lozova, V. I. (2000). Tsilisnyi pidkhid do formuvannya piznaval'noyi aktyvnosti shkolyariv, ATS, Kharkiv, Ukraine, 164 p. [in Ukrainian]

[2] Bykov, V. Yu., Leshchenko, M. P. (2016). Tsyfrova humanistychna pedahohika: aktual'ni problemy pedahohichnykh doslidzhen' u haluzi vykorystannya IKT v osviti, Information Technologies and Learning Tools, 53(3), 1-17. DOI: https://doi.org/10.33407/ittt.v53i3.1417 
[3] Malach, J. et al. (2016). Objectives and Content of E-module "Tools for Adaptive Learning. Learning Styles" within the MOOC Course "ICT Tools for E-learning", International Journal of Research in E-learning, 2(1), 28-40.

[4] Simonova, I., Ustiugova, T., Yakovleva, O. (2017). The Impact of Online Services on Developing Students' Media Competence, International Journal of Research in E-learning, 3(2), 35-48.

[5] Poyasok, T. B., Bespartochna, O. I. (2018). Orhanizatsiya pedahohichnoyi vzayemodiyi uchasnykiv osvitn'oho protsesu v komp"yuterno oriyentovanomu navchal'nomu seredovyshchi zakladu vyshchoyi osvity, Information Technologies and Learning Tools, 67(5), 199-212. DOI: https://doi.org/10.33407/itt.v67i5.2110

[6] Bahmat, N. V., Kartashova, L. A. (2016). Organization of teacher's professional activity in conditions of innovative educational environment, Informational Technologies in Education, 27, 31-40.

[7] Morze, N., Buinytska, O. (2016). E-learning Managers Training to Design High-tech Electronic Learning Environment, International Journal of Research in E-learning, 2(2), 11-27.

[8] Morze, N., Buinytska, O. (2015). Open E-environment - The Key Instrument of the Education Quality, International Journal of Research in E-learning, 1(1), 27-46.

[9] Morze, N. V., Buynyts'ka, O. P. (2017). Pidvyshchennya rivnya informatsiyno-komunikatsiynoyi kompetentnosti naukovopedahohichnykh pratsivnykiv - klyuchova vymoha yakosti osvitn'oho protsesu, Information Technologies and Learning Tools, 59(3), 189-200. DOI: https://doi.org/10.33407/ittt.v59i3.1667

[10] Khivrych, V. (2015). The Experience of the Creation of Educational IT Space of the Region, International Journal of Research in E-learning, 1(2), 70-85.

[11] Mukii, T. V. (2016). The Development of Key Student Competencies While Studying Computer Science in Secondary School, International Journal of Research in E-learning, 1(2), 103-118.

[12] Koltok, L. (2015). Vykorystannya IKT na urokakh yak odna iz skladovykh modernizatsiyi pochatkovoyi shkoly, Youth and Market, 9(128), 112-116. [in Ukrainian]

[13] Lapins'kyy, V. V. (2008). Komp'yuterno oriyentovane navchal'ne seredovyshche ta vymohy do yogo realizatsiyi, Scientific Notes. Series: Pedagogical sciences, 77(1), RVV KDPU im. V. Vynnychenka, Kirovohrad, Ukraine, 79-85. [in Ukrainian]

[14] Tryus, Yu. V. (2005). Komp'yuterno-oriyentovani metodychni systemy navchannya: monografiya, Brama-Ukrayina, Cherkasy, Ukraine, 400 p. [in Ukrainian]

[15] Bystryantsev, M. (2016). Stvorennya informatsiyno-osvitn'ogo prostoru zahal'noosvitn'oyi shkoly, Native school, 10, 19-24. [in Ukrainian]

[16] Havrylyuk, S. (2015). Vykorystannya IKT na urokakh informatyky, URL: https://lana01091966.io.ua/ s2289203/vikoristannya_ikt_na_urokah_informatiki (accessed 4, March 2019). [in Ukrainian]

[17] Hashporenko, T. V. (2016). Vykorystannya informatsiyno-komunikatsiynykh tekhnologiy na urokakh informatyky v pochatkoviy shkoli, Proceedings of Internet conference of pedagogical staff of Kropyvnitsky Methodological and SocialPsychological Service Center (January 2016), URL: http://cmsps.edukit.kr.ua/metodichna_robota//sichneva_internetkonferenciya_2016/pn/2/ (accessed 12, March 2019). [in Ukrainian]

[18] Holovata, M. L. (2014). Vykorystannya informatsiyno-komp'yuternykh tekhnologiy na urokakh informatyky ta v pozaurochnyi chas, URL: http://golovata.dimca.cv.ua/wp-content/uploads/2014/01/Nykorystannya-informatsiyno-kompyuternykhtekhnolohiy-na-urokakh-informatyky-ta-v-pozaurochnyy-chas.pdf (accessed 12, March 2019). [in Ukrainian]

[19] Panchenko, H. D. (2012). Informatsiyno-osvitnye seredovyshche v profesiyniy pidgotovtsi vchytelya, Teacher education: theory and practice, 11, 69-81. [in Ukrainian]

[20] Lytvynova, S. (2014). Rozvytok navchal'nogo seredovyshcha zahal'noosvitn'ogo navchal'noho zakladu yak naukova problema, Scientific Transactions of Melitopol State Pedagogical University. Series: Pedagogy, 1(12), 39-47. [in Ukrainian]

[21] Zhaldak, M. I. (2017). Informatyka dlya uchniv 5-9 klasiv, yaki vyvchaly informatyku u 2-4 klasakh: navchal'na programa, MON Ukrayiny, Kyiv, Ukraine, 24 p. URL: https://mon.gov.ua/storage/app/media/zagalna serednya/programy-5-9klas/onovlennya-12-2017/8-informatika.docx (accessed 10, March 2019). [in Ukrainian]

[22] Grytsiuk, O. S. (2018). Komp'yuterno-oriyentovane navchal'ne seredovyshche vchytelya informatyky, Modern movement of science: Proceedings of IV International scientific and practical internet conference (Dnipro, 6-7 December 2018), WayScience, Dnipro, Ukraine, 318-323. URL: http://www.wayscience.com/wp-content/uploads/2018/12/Zbirnik-tezdopovidey-IV-mizhnarodnoyi-naukovo-praktichnoyi-internet-konferentsiyi.pdf (accessed 11, March 2019). [in Ukrainian]

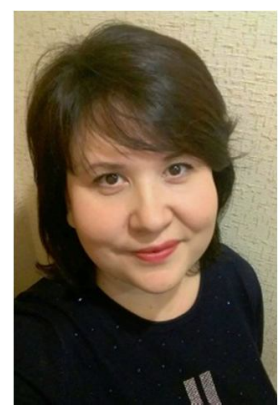

Грицюк Олена Сергіївна.

кандидат педагогічних наук, доцент, доцент кафедри інформатики і вищої математики,

Кременчуцький національний університет імені Михайла Остроградського,

вул. Першотравнева, 20, м. Кременчук, Україна, 39600

Тел. (05366) 3-00-50. E-mail: hrytsiuk.elena@gmail.com

\section{Grytsiuk Olena Serhiivna.}

PhD (Ped.), Associated Professor, Associated Professor of Mathematics and Computer Science Department Kremenchuk Mykhailo Ostrohradskyi National University,

Pershotravneva st, 20, Kremenchuk, Ukraine, 39600

Tel. +38(05366)30050. E-mail: hrytsiuk.elena@gmail.com

ORCID: http://orcid.org/0000-0003-2117-626X 


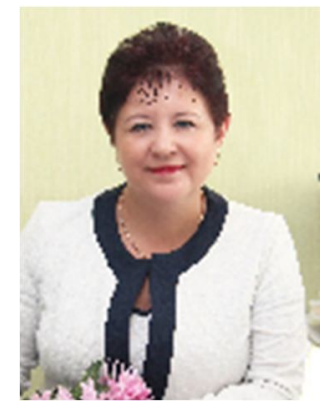

Шаповал Олена Анатоліївна

директор ліцею,

Кременчуцький ліцей №6 «Правобережний» Кременчуцької міської ради Полтавської області адреса: вул. Олександра Білаша, 32, м. Кременчук, Україна, 39600.

Тел. (05366) 6-01-54. E-mail: gimnasiumsix@i.ua

\section{Shapoval Olena Anatoliivna}

Lyceum Director,

Kremenchuk Pravobereghnyi Lyceum № 6 Kremenchuk Town Council Poltava region,

Oleksandr Bilasha st, 32, Kremenchuk, Ukraine, 39600.

Тел. (05366) 6-01-54. E-mail: gimnasiumsix@i.ua

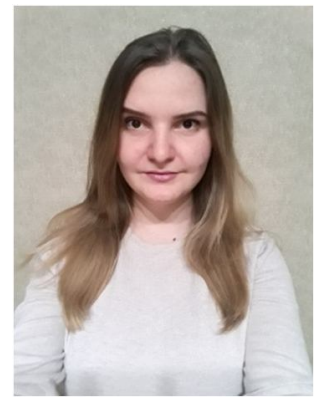

\section{Опришко Анастасія Володимирівна.}

вчитель інформатики,

Кременчуцький ліцей №6 «Правобережний» Кременчуцької міської ради Полтавської області адреса: вул. Олександра Білаша, 32, м. Кременчук, Україна, 39600.

Тел. +380962829916. E-mail: asyagri96@gmail.com

\section{Opryshko Anastasia Volodymyrivna.}

Teacher of Informatics

Kremenchuk Pravobereghnyi Lyceum № 6 Kremenchuk Town Council Poltava region

Oleksandr Bilasha st, 32, Kremenchuk, Ukraine, 39600

Тел. +380962829916. E-mail: asyagri96@gmail.com

\section{Citation (APA):}

Grytsiuk, O., Shapoval, O., Opryshko, A. (2019). Information and education environment as a condition of senior students' cognitive activity growing using ICT. Engineering and Educational Technologies, 7 (2), 105-113. doi: https://doi.org/10.30929/2307-

9770.2019.07.02.11

\section{Цитування (ДСТУ 8302:2015):}

Грицюк О. С., Шаповал О. А., Опришко А. В. Інформаційно-освітнє середовище як умова активізації пізнавальної діяльності учнів засобами IКT / Інженерні та освітні технології. 2019. Т. 7. № 2. С. 105-113. doi: https://doi.org/10.30929/23079770.2019 .07 .02 .11

Обсяг статmі: $\quad$ сторінок- 9 ; умовних друк. аркушів - 1,304. 